$$
\begin{aligned}
& \text { 水素圧力センサーダイヤフラムの破損解析 }{ }^{\dagger} \\
& \text { 宮 本 泰 介* 金 崎 俊 彦** 田崎治 彦*** } \\
& \text { 小 林 信 } \text { 夫 }^{*} \text { 松 岡 三 郎 } \text { *** }^{*} \text { 村 上 敬 宜 }{ }^{* * *}
\end{aligned}
$$

\title{
Failure Analysis on the Diaphragm of a High Pressure Hydrogen Transducer
}

by

\author{
Taisuke Mryamoto ${ }^{*}$, Toshihiko KanaSAKI ${ }^{* *}$, Haruhiko TASAKI ${ }^{* * *}$, \\ Nobuo KobaYAshi ${ }^{*}$, Saburo Matsuoka ${ }^{* * * *}$ and Yukitaka MuraKami ${ }^{* * * *}$
}

The failure analysis of a high pressure hydrogen transducer which was actually used in a test equipment of $70 \mathrm{MPa}$ hydrogen gas exposure vessel was carried out. A crack existed at the root of flange of diaphragm in the transducer and a small amount of hydrogen leaked through the crack. EDSD analysis and Vickers hardness measurement confirmed that a diaphragm material was a precipitation hardened stainless steel SUS630. SEM observation showed that intergranular fracture surfaces with the size of about $20 \mu \mathrm{m}$ were formed at the root of flange and that dimple, quasi-cleavage and intergranular fracture were sequentially observed away from the flange root. The stress analysis and hydrogen invasion analysis of diaphragm were conducted. Using the plate of SUS630, the hydrogen diffusion coefficient and solubility, and the threshold stress intensity factor of hydrogen assisted cracking under static loading were measured. The diaphragm was fixed to the pressure transducer by bolt end. The elastic principal stress at the flange root by bolt end was about three times higher than the tensile strength of $1358 \mathrm{MPa}$ of the diaphragm. It was presumed that the $20-\mu \mathrm{m}-$ long intergranular crack initiated at the flange root by the high principal stress and propagated by hydrogen embrittlement.

Key words : Hydrogen embrittlement, High pressure, Pressure transducer, Failure analysis, Precipitation hardened stainless steel

\section{1 緒言}

地球環境保護や石油資源枯渇問題から，自動車産業に おいても石油に代わるエネルギーへの転換の取り組みが 積極的に行われている，その中で，水素を燃料とする燃 料電池（固体高分子型）は，石油資源を燃料とする内燃 機関に代わる有力な動力源候補と見なされ, NEDOのプ ロジェクトでも推進されている，燃料電池自動車の場合， 燃料の水素は車両に積載された高圧水素タンクから燃料 電池に供給する方法が最も実用的とされている。当初は, $35 \mathrm{MPa}$ から始まった高圧タンクは，車の航続距離を長く し, タンク容積を小さくする必要から現在 $70 \mathrm{MPa}$ とい う高圧水素が選択されている。この高圧水素を燃料電池 自動車に供給する水素ステーションでは, $90 \mathrm{MPa} レ$ レ゙ の高圧水素を貯蔵することが求められている。しかしな がら，このような高圧水素を日常的に扱うための技術は， まだ十分に蓄積されてはいない，その中でも，金属材料 に水素原子が侵入することにより材料がもろくなり，場
合によっては破損に繋がる可能性のある水素ぜい化を克 服することは，避けて通れない課題となっている，水素 ぜい化の克服のためには, 水素ぜい化の研究と同時に水 素ぜい化に関係する部品や部材の破損・損傷の事例解析 の積み重ねも必要である。現在, 高圧水素ステーション や高圧水素実験設備は限定された場所にしか存在しない ので，まずここで経験した破損・損傷事例を開示し，解 析した実績を蓄積する必要がある。こうした考えに基づ き，本論文では，高圧水素試験装置で使用していた析出 強化型マルテンサイト系ステンレス鋼 SUS630 製の水素 圧力センサーの破損（水素微小漏れ）事例を報告する. センサーの破損が水素によるものかどうかを判定するこ とはかなり難しいが, 圧力センサーメーカの協力による 設計情報の入手, 使用履歴の調査に加え, ダイヤフラム での応力解析, 水素侵入解析, 破面観察を行った結果, センサーの破損は水素が影響した破損であると結論する に至った。

$\dagger$ 原稿受理 平成 22 年 4 月 12 日 Received Apr. 12, 2010 @ 2010 The Society of Materials Science, Japan

* トヨタ自動車(株) FC 開発部 † 471-8571 豊田市卜ヨタ町, Fuel Cell System Div., Toyota Motor Co., Toyota-cho, Toyota, 471-8571

** 九州大学大学院工学府 (現在 本田技研工業(制)＝819-0395 福岡市西区元岡, Graduate student, Graduate School of Eng., Kyushu Univ., (Honda Co., Ltd.) Nishi-ku, Fukuoka, 819-0395

*** 九州大学大学院工学府 (現在 日揮(株)）＝819-0395 福岡市西区元岡, Graduate student, Graduate School of Eng., Kyushu Univ., (JGC Co.) Nishi-ku, Fukuoka, 819-0395

**** 正 会 員 九州大学大学院工学研究院機械工学部門産業技術総合研究所水素先端材料科学研究センター = $819-0395$ 福岡市西区元岡, Dept. of Mech. Eng., Kyushu Univ. and Res. Center of Hydrogen Industrial Use and Storage (HYDROGENIUS), National Inst. of Advanced Industrial Sci. and Tech. (AIST), Nishi-ku, Fukuoka, 819-0395 


\section{2 破損した圧カセンサーの使用履歴と外観調査}

最大圧力 $70 \mathrm{MPa}$ で $200^{\circ} \mathrm{C}$ まで加熱できる圧力容器の圧 力を測定するためのセンサー (Fig. 1) が少量の水素漏れ を起こした。このセンサーは $150 \mathrm{MPa}$ 対応の市販品であ り, 水素ガス中ではメーカ保証は無いものである. 水素 漏れを起こした圧力センサーは, 高圧容器に最も近く, 容器加熱ヒータの熱を受けやすいところにあった。一方， 他にも同じセンサーが異なる部位で使用されているが， 水素漏机を起こさず正常に作動している.

Table 1 には圧力センサーの使用履歴をまとめて示す. センサーに圧力を負荷した回数は合計で 64 回であった. Fig. 2 には，センサーが水素漏れを起こす前の半年間の 使用履歴を示す．水素漏れ直前にはセンサーは $70 \mathrm{MPa}$ の圧力で $50 \sim 200 \mathrm{~h}$ 保持の負荷状態が断続的に続く状態

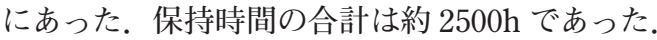

Fig. 3 には，水素漏れを起こしたセンサーの圧力検知 部であるダイヤフラムの寸法と組立図を示す。ダイヤフ ラムは締付ボルト（管用ねじ）により固定されている.
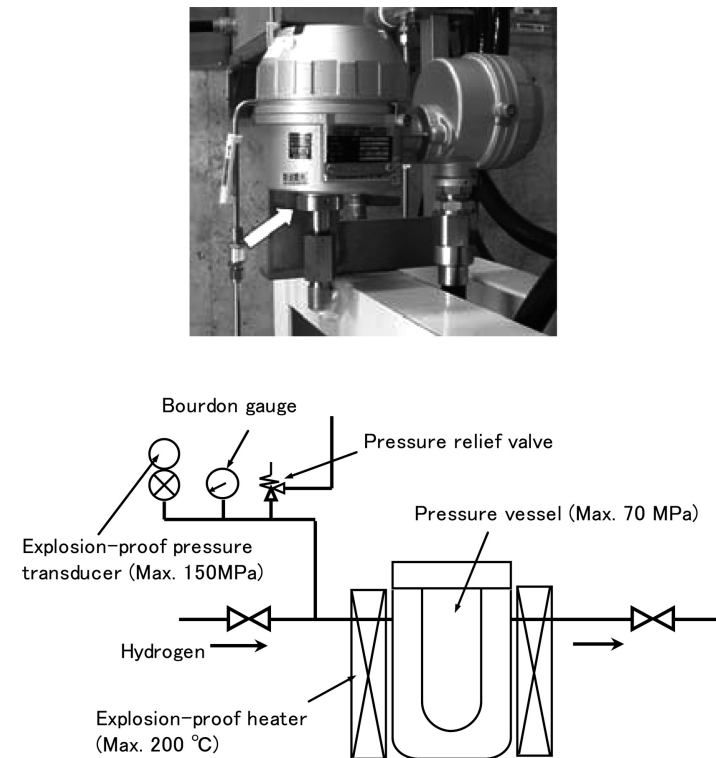

Fig. 1 Pressure transducer and it's placement in the test Equipment.

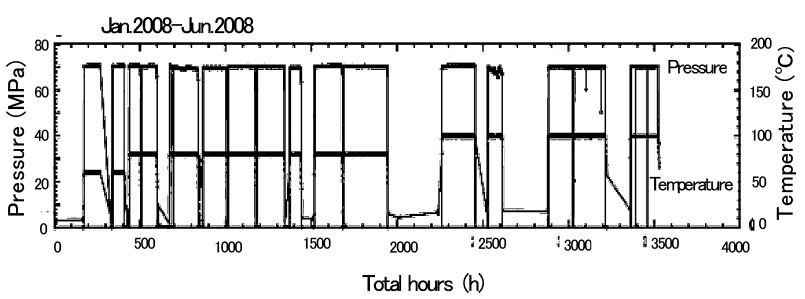

Fig. 2 History of pressure and vessel temperature before sensor damage.

Table 1 Summary of usage history of high pressure sensor.

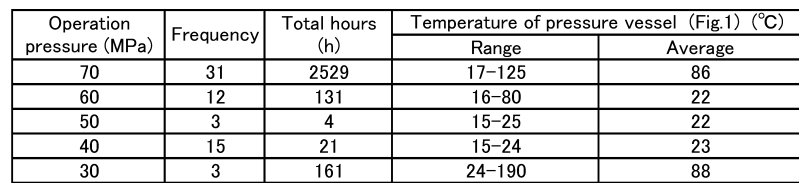

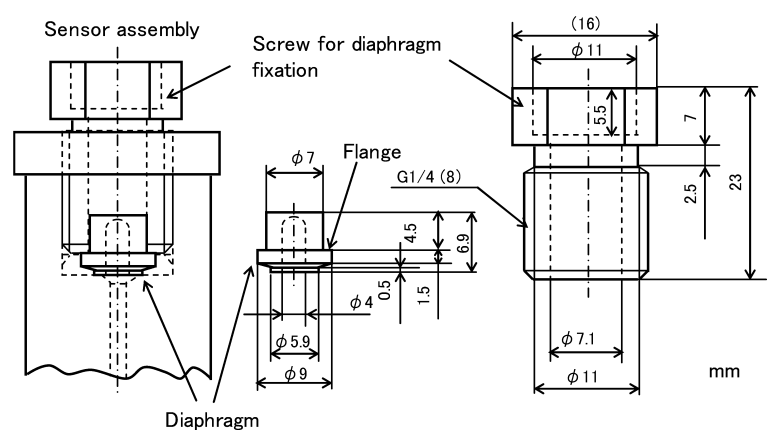

Fig. 3 Dimensions and assembly drawing of a diaphragm of pressure transducer.

Fig. 4 に破損したダイヤフラムを示す。き裂はフランジ の R 部（隅肉部，大気側）と，攵れと対応する内面（高 圧水素側）に存在し，中空円柱形状のダイヤフラムの半 周程度の範囲に存在していた。ダイヤフラムは完全に破 壊していなかったので, 水素はき裂から少量リークした。

\section{3 破損したダイヤフラムの調査}

\section{$3 \cdot 1$ 試料の取り出し}

き裂経路の外観観察をした後，硬さ測定や破面観察を 行うため, Fig. 5 に示す位置においてマイクロカッチン グで切断した。切断でダイヤフラムは 3 つに分かれたが, それぞれを試料 A，試料 B，試料 C と名付けた。

\section{$3 \cdot 2$ 材質調查}

試料 A，B，C はどれも小さいため，エネルギー分散型 X線分光分析 (EDS) により化学成分分析を行った。予 め標準試料を用いて校正した。試料 A を樹脂に埋め込み, 切断面をバフ研磨した後に，分析に用いた．Table $2 に ，$

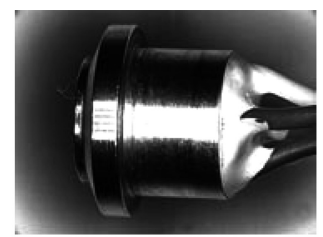

(a) Diaphragm

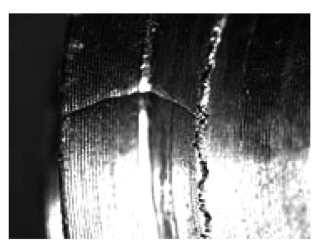

(b)Crack at the root of flange at the outer surface

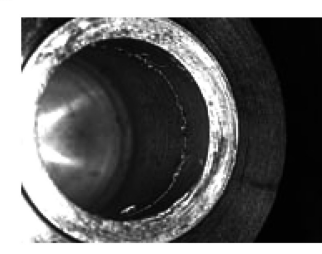

(c) Crack at the inner surface of diaphragm
Fig. 4 Cracked diaphragm.

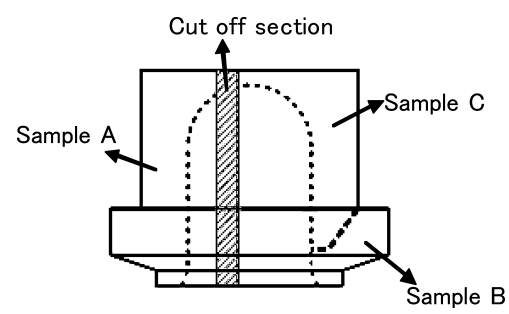

Fig. 5 Cut off section and location of samples A, B and C. 
Table 2 Chemical composition of diaphragm sample. (mass\%)

\begin{tabular}{|c|c|c|c|c|c|c|c|c|c|}
\hline Details & $\mathrm{C}$ & $\mathrm{Si}$ & $\mathrm{Mn}$ & $\mathrm{P}$ & $\mathrm{S}$ & $\mathrm{Cu}$ & $\mathrm{Ni}$ & $\mathrm{Cr}$ & $\mathrm{Nb}$ \\
\hline EDS analysis & - & $(0.5)$ & - & - & - & 3.2 & 4.2 & 15.7 & $(0.6)$ \\
\hline SUS630(JISG4303) & $<0.7$ & $<1.00$ & $<1.00$ & $<0.04$ & $<0.03$ & $3.00 / 5.00$ & $3.00 / 5.00$ & $15.00 / 17.50$ & $0.15 / 0.45$ \\
\hline
\end{tabular}

EDS により求めた化学成分と JIS 規格で定める SUS630 の化学成分範囲を示す。 $\mathrm{Cu}, \mathrm{Ni}, \mathrm{Cr}$ の量が JIS 規格 (JIS G 4303) で定める範囲内にあることから，ダイヤフラ ムの材料は析出硬化型マルテンサイト系ステンレス鋼 SUS630 であると判断できる。

Fig. 6 に, 試料 A に打いてビッカース硬さ測定を行っ た位置および測定值を示す．5点のビッカース硬さの平 均值は HV 417 であった. ダイヤフラム全体にわたって HV 420 前後であることから, ダイヤフラムにはJIS S 4303 で決める H900（固溶化熱处理 $1020 \sim 1060^{\circ} \mathrm{C}$ 急冷, 析出硬化熱処理 $470 \sim 490^{\circ} \mathrm{C}$ 空冷, $\mathrm{HRC} 40$ 以上）の時 効处理が施されていることがわかる，HRC 40 はほぼ HV 400 に相当する.

Fig. 7 に電子後方散乱回折法 (EBSD) により得たダイ ヤフラムの材料組織を示す。観察した位置は, Fig. 6 に 示すフランジ付け根周辺部である. Fig. 7 よりダイヤフ ラムの材料はマルテンサイト組織を有していることがわ かる.

\section{$3 \cdot 3$ 縦断面と破面の観察}

Fig. 8 に試料 A および試料 B の縦断面の写真を示す. 最初に破損部品を観察した時には，水素の直接影響の強 い内壁からき裂が発生, 進展したのではないかという意 見もあった。しかし，もしそうであればき裂は最大の応 力である円周方向応力に垂直な面に沿って発生するはず であり，午の結果内壁には軸方向のき裂が観察されるは ずである。しかし，実際は内壁のき裂は円周方向である から, き裂の発生起点は内壁ではなく応力集中の大きい フランジ付け根であると推定された。このような理由か ら Fig. 8 (a)に打いては，き裂はフランジ付け根の R 部

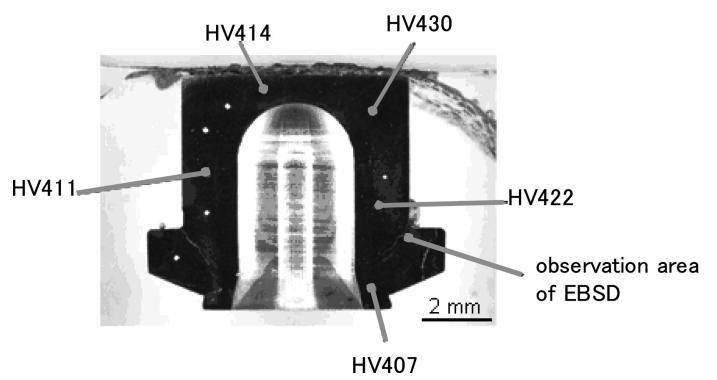

Fig. 6 Vickers hardness of diaphragm. (sample A)

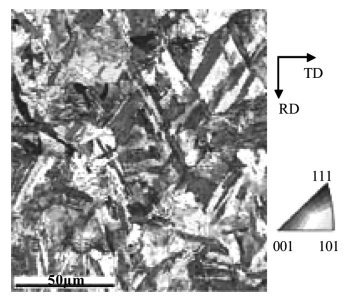

Fig. 7 EBSD image of diaphragm. (sample A)

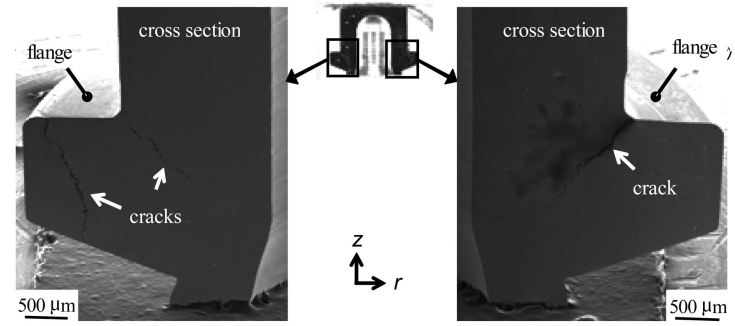

(a) Sample A

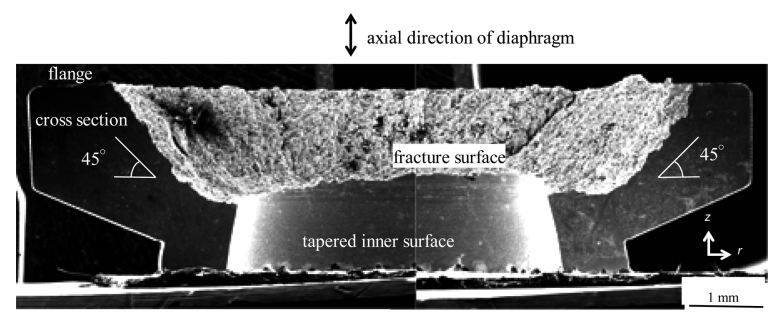

(b) Sample B

Fig. 8 SEM observation of longitudinal sections of sample A and B.

で発生・進展し，途中で停止したことが予測できる. Fig. 8 (b)からは, フランジ付け根の R 部に発生したき裂 は，ダイヤフラム軸方向 $\left(\mathrm{z}\right.$ 方向）と約 $45^{\circ}$ をなす方向 に進展したのち, 内面付近になると, ダイヤフラム軸方 向（z 方向）と垂直な方向に進展したことがわかる.

Fig. 9 に, ダイヤフラムに打けるき裂進展状態図を示す. この図は, Fig. 4 でのダイヤフラム内面と外面 (R 部) で のき裂進展経路の観察並びに Fig. 8 での試料 A と B の 縦断面でのき裂進展経路の観察並びに Fig. 8 でのき裂進 展経路の観察と合わせて作成した。き裂進展状態図から， き裂は試料 B（抒よび試料 C）の中央付近のフランジ付 け根から発生したものと推察できる. Fig. 9 には，き裂 が試料 B（または試料 C）の中央付近で発生したと仮定 して求めた，き裂前縁の変化も矢印の実線で示してある.

Fig. 10 に, 試料 B の破面観察の結果を示す。破面に は，ディンプル，擬へき開破面，粒界破面がみられた。 Fig. 11 には, ディンプル，擬へき開破面，粒界破面の拡 大図を示す，破面を外周側から内周側へ見ていくと，き 裂が発生したと考えられる外周沿いには擬へき開もしく は粒界破面がみられた。外周沿いから少し内側になると ディンプルが多く観察されるようになる。ディンプルは 破面中央付近まで存在したが, 最終破断部の内周側に近 くなるとディンプルは観察されなくなり，擬へき開もし くは粒界破面が支配的であった。

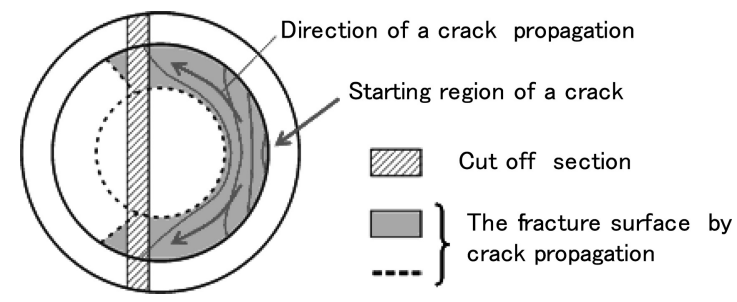

Fig. 9 Estimation of the crack path. 


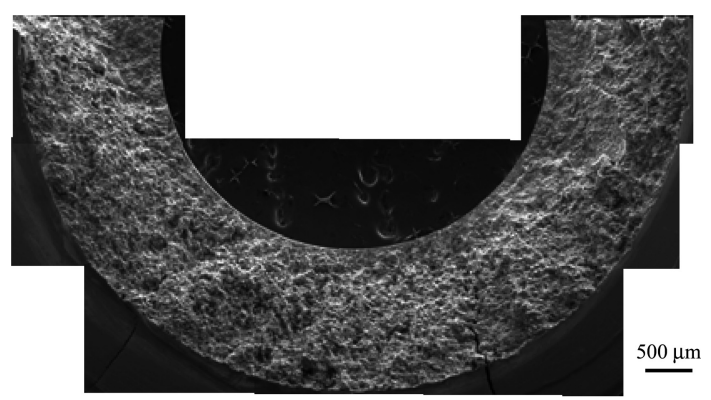

(a) Fracture surface of diaphragm sample B

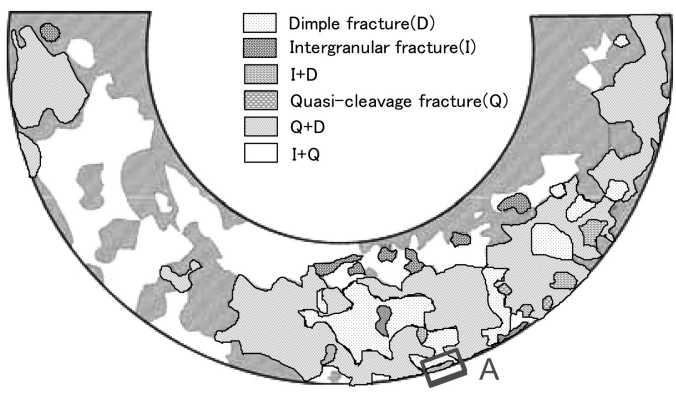

(b) Fractographic difference of diaphragm sample B

Fig. 10 Fracture surface and illustration of fractographic difference of diaphragm sample B.

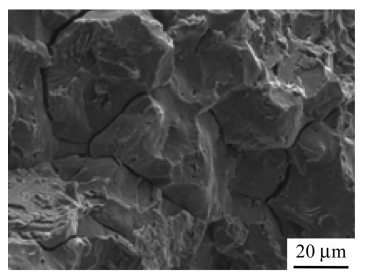

(a)Intergranular fracture pattern

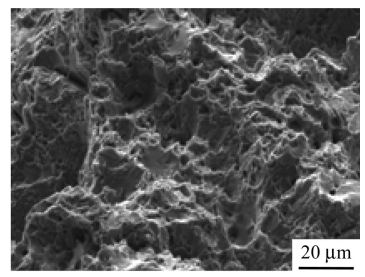

(b) Dimple fracture pattern

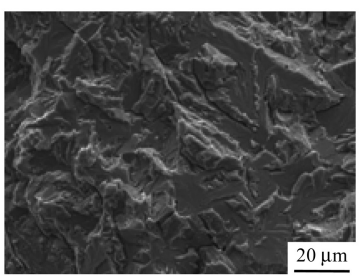

(c) Quasi-cleavage fracture pattern

Fig. 11 Three types of fracture appearance observed on the fracture surface.

き裂は試料 B の中央付近のフランジ付け根から発生し たと考えられることを示した (Fig. 9). Fig. 10 (b)から， 試料 Bにおいて，ディンプル破面は中央よりも少し右側 で多く観察された。このことから，き裂は試料 B の中央 よりも少し右側で発生したものと考えられる.Fig. 12 に, Fig. 10 (b)の A に示す部分の拡大写真を示す。き裂 の発生起点と考えられるフランジ付け根では, Fig. 12 に 示すように, 直径 $20 \mu \mathrm{m}$ 程度の粒界破面が複数観察され た。このフランジ付け根で観察される粒界破面の周りに は擬へき開破面，ディンプル破面が観察された。

Beachem ${ }^{1)}$ は, 高強度の焼戻しマルテンサイト鋼の WOL 試験片を用い，一定変位負荷き裂進展試験を応力

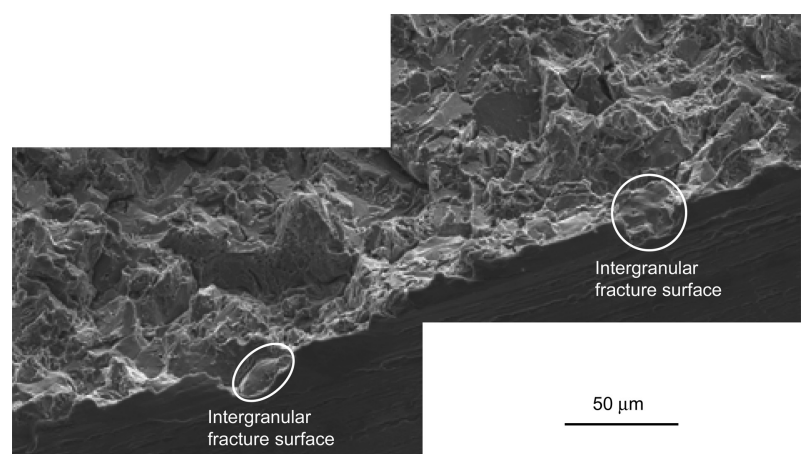

Fig. 12 Intergranular fracture surface observed around the root of flange. [Magnification of A in Fig. 10 (b)]

腐食割れ環境下と水素チャージ環境下で行っている。こ の試験では，き裂が長くなると，応力拡大係数 $K$ が低下 する.

彼の結果によると，Kが大きいところでは，ディンプ 儿破面が形成され，Kが減少するにしたがって，擬へき 開破面，粒界破面が形成される.

以上のことを考慮すると，フランジ付け根の応力集中 部で引張応力により粒界割れが発生し，その粒界割れを 起点として, 水素に助長されてき裂が進展したと推察で きる。

\section{4 検討および考察 \\ $4 \cdot 1$ 水素拡散速度, 飽和水素量と水素助長割れ下限 界応力拡大係数の測定}

水素漏洩を起こした压力センサーの損傷解析を行うた め，別途入手した SUS630 を用いて水素拡散速度，飽和 水素量, 並びに水素助長割机下限界応力拡大係数を求め た. Table 3 に用いた材料の化学成分を示す。測定は溶 体化処理材と析出硬化材とについて実施した。溶体化処 理は, $1038^{\circ} \mathrm{C}$ 加熱後空冷, 時効処理は, 溶体化処理後, $490^{\circ} \mathrm{C}$ で $6 \mathrm{~h}$ 加熱とした。硬さは，析出硬化材で HV 433 であり，溶体化処理材で HV 344 であった（測定条件： 荷重 $9.8 \mathrm{~N}$, 保持時間 $30 \mathrm{~s}, 20$ 点平均)。硬さ測定におけ るばらつきは，すべて $\pm 3 \%$ 以内であった。

$4 \cdot 1 \cdot 1$ 水素拡散速度の測定 溶体化処理材および 析出硬化材に打ける水素の拡散係数を調べるために， Fig. 13 に示すように, 直径 $13 \mathrm{~mm}$ の円柱状試料の側面 を絶縁テープで被覆し, 水素が円柱端面からのみ侵入す るようにして，陰極チャージを行った。陰極チャージは， 白金陽極を用い, $80^{\circ} \mathrm{C}$ に保持した $\mathrm{pH} 3.5$ の硫酸水溶液 中に扑て電流密度 $i=27 \mathrm{~A} / \mathrm{m}^{2}$ で $168 \mathrm{~h}$ 行った. Fig. 13 に示すように，陰極チャージ後に，厚さ $0.5 \mathrm{~mm}$ のチップ を端面から深さ方向に $1 \mathrm{~mm}$ 間隔で切り出し, 液体窒素 中に保存したのち，チップの水素量を四重極質量分析型 昇温脱離分析装置 (TDS) により，昇温速度 $0.5^{\circ} \mathrm{C} / \mathrm{s}$ で

Table 3 Chemical composition of specimen. (mass \%)

\begin{tabular}{|c|c|c|c|c|c|c|c|c|}
\hline $\mathrm{C}$ & $\mathrm{Si}$ & $\mathrm{Mn}$ & $\mathrm{P}$ & $\mathrm{S}$ & $\mathrm{Cu}$ & $\mathrm{Ni}$ & $\mathrm{Cr}$ & $\mathrm{Nb}$ \\
\hline 0.04 & 0.32 & 0.77 & 0.025 & 0.011 & 3.27 & 4.73 & 15.46 & 0.40 \\
\hline
\end{tabular}



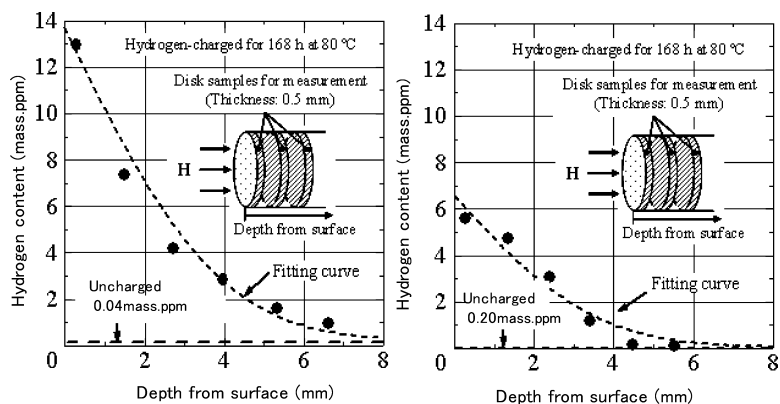

(a) Solution treated specimen

(b) Precipitation hardened specimen

Fig. 13 Hydrogen content distribution in hydrogencharged cylinder specimen.

測定した．陰極チャージ終了から水素量測定までの間に， チップが大気に曝された時間は $2 \mathrm{~h}$ 未満である。得られ た結果を Fig. 13 に示す。これらの結果から，水素拡散 係数 $D$ を式 (1)を用いて最小自乗法により求めた。

半無限体の表面から水素が侵入するとき，表面からの 水素濃度分布は次式により計算できる。2)

$$
C(z, t)=\left(C_{\mathrm{S}}-C_{\mathrm{U}}\right)\left\{1-\operatorname{erf}\left(\frac{z}{2 \sqrt{D t}}\right)\right\}+C_{\mathrm{U}}
$$

ここで, $C$ : 時間 $t(\mathrm{~s})$, 深さ $z(\mathrm{~m})$ に打ける水素濃度, $C_{\mathrm{S}}$ : 試料表面に拈ける水素量, $C_{\mathrm{U}}$ : 未チャージ材の水素 量, $D$ : 水素の拡散係数 $\left(\mathrm{m}^{2} / \mathrm{s}\right)$, erf : 䛊差関数である. 円柱状試料に打いて，水素が円柱端面のみから侵入する 場合の水素侵入挙動は，水素侵入深さが浅ければ，半無 限体の表面からの水素侵入挙動と同等である。したがっ て, 円柱端面からの水素濃度分布 (Fig. 13) を求めれば, 式 (1)から水素の拡散係数を求めることができる.

$80^{\circ} \mathrm{C}$ に打ける水素の拡散係数 $D_{353 \mathrm{~K}}$ は, 溶体化処理材 では $D_{353 \mathrm{~K}}=7.6 \times 10^{-12} \mathrm{~m}^{2} / \mathrm{s}$ ，析出硬化材では $D_{353 \mathrm{~K}}=6.4 \times$ $10^{-12} \mathrm{~m}^{2} / \mathrm{s}$ であった。 また，Fig. 13 中に示すように，溶 体化処理材では $C_{\mathrm{U}}=0.2$ mass.ppm, $C_{\mathrm{s}}=13.7$ mass.ppm, 析出硬化材では $C_{\mathrm{U}}=0.04$ mass.ppm, $C_{\mathrm{s}}=6.6 \mathrm{mass} . \mathrm{ppm}$ であった. 析出硬化材の拡散係数は溶体化処理材より約 15\% 小さい. 析出硬化材では, 銅の析出物が水素をトラッ プし, 水素の拡散を遅くしていると考えられる.

$4 \cdot 1 \cdot 2$ 飽和水素量の測定 フガシティ $F$ を適応し たジーベルツ則 ${ }^{3)}$ を用いると, 圧力 $p(\mathrm{MPa})$, 温度 $T(\mathrm{~K})$ の水素ガス中に打ける材料中の飽和水素量 $C_{\mathrm{HS}}$ (mass. ppm) は次式で表される.

$$
\begin{aligned}
& C_{\mathrm{HS}}=\alpha \sqrt{F} \exp \left(-\frac{\Delta H_{\mathrm{S}}}{\mathrm{R} T}\right) \\
& F=p \exp \left(\frac{p b}{\mathrm{R} T}\right)
\end{aligned}
$$

$C_{\mathrm{HS}}$ :Saturated hydrogen content (mass.ppm), $F$ : Fugacity, $H_{\mathrm{S}}$ : Enthalpy of hydrogen solution ( $/ \mathrm{mol}), \alpha$ : Const., $b$ : Const. $\left(15.84 \mathrm{~cm}^{3} / \mathrm{mol}\right),{ }^{3)} R$ : Gas constant [8.314 J/(mol-K)], $p$ : Pressure [MPa].

Fig. 14 に, 高圧水素に曝露した直径 $7 \mathrm{~mm}$, 厚さ $2 \mathrm{~mm}$ の円盤状チップの飽和水素量 $C_{\mathrm{HS}}$ と水素ガス圧力 $p$, 温度 $T$ を用いたパラメータの関係を示す。なお，水

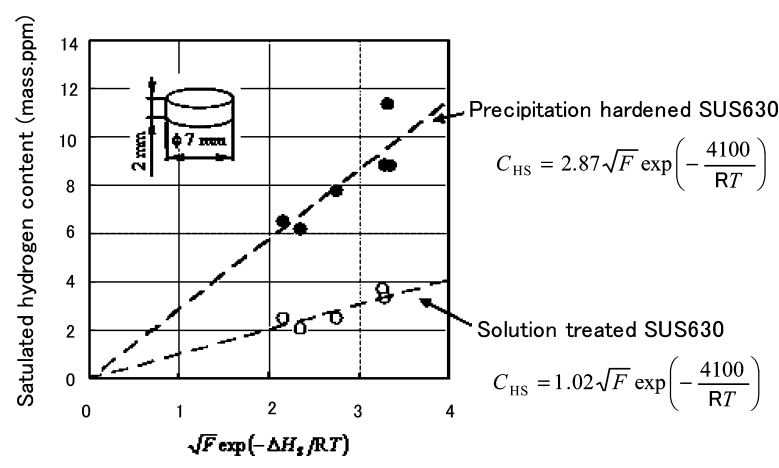

Fig. 14 Relationship among saturated hydrogen content $C_{\mathrm{HS}}$, hydrogen pressure $\mathrm{p}$ and temperature $T$ of precipitation hardened and solution treated specimen. (Hydrogen was charged by exposure to high-pressure hydrogen gas)

素の溶解熱 $\Delta H_{\mathrm{S}}$ には, T-P. Perng ら $^{4)}$ がフェライト系ス テンレス鋼 AL29-4-2 で求めた, $\Delta H_{\mathrm{S}}=4.1 \mathrm{~kJ} / \mathrm{mol}$ を用い た。同じ圧力，温度の水素䨌囲気に扎いて，析出硬化材 の $C_{\mathrm{HS}}$ は溶体化処理材の約 3 倍である．析出硬化材では， 銅の析出物が水素をトラップするため, 飽和固溶水素量 が大きいと考えられる。

Fig. 14 に示すデータを用いて, 式 (2)から最小自乗法 により定数 $\alpha$ を求めると, 析出硬化材では $\alpha=2.87$, 溶 体化処理材では $\alpha=1.02$ である. 飽和水素量と水素ガス の温度, 圧力の関係は次式のように表される。

$$
\begin{aligned}
& \text { 析出硬化材 } \quad C_{\mathrm{HS}}=2.87 \sqrt{F} \exp \left(-\frac{4100}{\mathrm{R} T}\right) \\
& \text { 溶体化処理材 } \quad C_{\mathrm{HS}}=1.02 \sqrt{F} \exp \left(-\frac{4100}{\mathrm{R} T}\right)
\end{aligned}
$$

\section{$4 \cdot 1 \cdot 3$ 水素助長割れの下限界応力拡大係数 $K_{\mathrm{th}, \mathrm{H}}$ の} 測定 静的負荷下に损いて, 水素助長割れを生じない $K_{\mathrm{th}, \mathrm{H}}$ を求めるために, 水素䨌囲気中において WOL 試験 片を用いた一定変位負荷き裂進展試験を行った。

Fig. 15 にはWOL 試験片の寸法を示す.WOL 試験片 については，析出硬化材と溶体化処理材ともに，板材の 圧延方向に水平または垂直な方向に切欠きを導入した 2 種類を用意した。試験は次の手順で行った。まずWOL 試験片に $K \geq 25 \mathrm{MPa} \sqrt{\mathrm{m}}$ となるようにボルトを締めて 荷重をかける (Fig. 16 も参照)。次に，ボルト締めした WOL 試験片を $100 \mathrm{MPa} ， 85^{\circ} \mathrm{C}$ の水素ガス中に $200 \mathrm{~h}$ 曝露 する. 曝露終了後, 試験片の背面にひずみゲージを取り

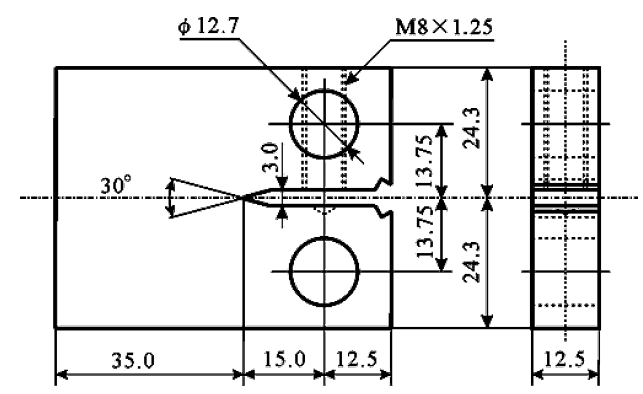

Fig. 15 Dimensions of WOL specimen. (mm) 

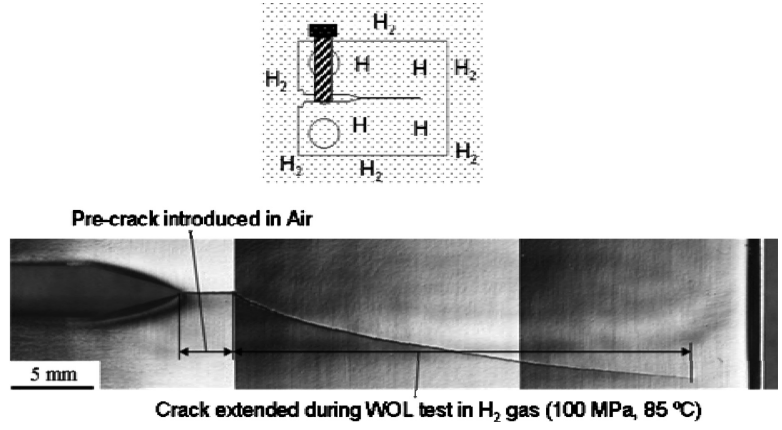

Fig. 16 Crack path of precipitation-hardened SUS630 WOL specimen.

付けて，ボルト除荷によるひずみ量を測定する。ひずみ量 からボルト締付けによる試験片への負荷荷重を求める。最 後に, 求まった負荷荷重とき裂長さから $K_{\mathrm{th}, \mathrm{H}}$ を求める.

Fig. 16 に, 試験後の WOL 試験片表面の様子を示す. ボルト締付けにより静的負荷をかけた状態で水素ガス中 にWOL 試験片を放置すると, き裂が進展する。しかし， き裂の進展に伴い $K$ は減少し， $K$ が $K_{\mathrm{th}, \mathrm{H}}$ になるとき裂 は進展しなくなる。200h 曝露時間が， $K_{\mathrm{th}, \mathrm{H}}$ を決めるの に対し十分な時間であるかを検証するために，一度曝露 した試験片のき裂長さを測定したのち，その試験片をも う一度 $100 \mathrm{MPa}, 85^{\circ} \mathrm{C}$ 水素ガスに曝露した。年の結果, き裂の進展はみられなかった。このことから，200h 曝露 時間は $K_{\mathrm{th}, \mathrm{H}}$ を求めるのに十分であると考えられる.

Fig. 17 に, WOL 試験で求めた析出硬化材执よび溶体 化処理材の $K_{\mathrm{th}, \mathrm{H}}$ を示す。試験片中の飽和水素量 $C_{\mathrm{HS}}$ は 式 (3)〜(5)を用いて計算した。析出硬化材と溶体化処理 材で比較すると, 溶体化处理材よりも析出硬化材のほう が $C_{\mathrm{HS}}$ は多く, $K_{\mathrm{th}, \mathrm{H}}$ は小さい。 また, き裂進展方向で比 較すると, 圧延方向に平行に進展するほうが圧延方向に 垂直に進展するよりも $K_{\mathrm{th}, \mathrm{H}}$ は小さい. 圧延により生じる 組織の異方性も $K_{\mathrm{th}, \mathrm{H}} に$ 若干影響を及ぼすと考えられる.

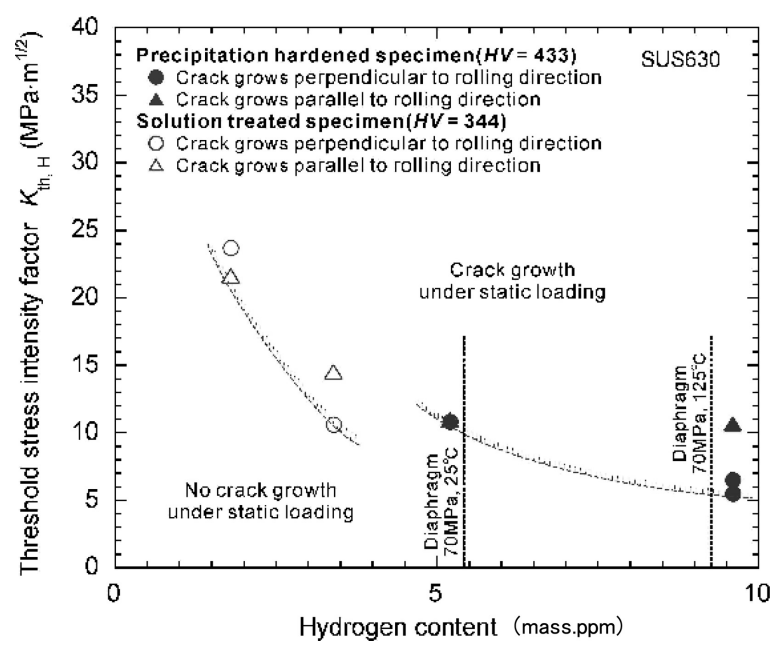

Fig. 17 Threshold stress intensity factor for hydrogen assisted cracking under static loading $K_{\mathrm{th}, \mathrm{H}}$ of precipitation hardened and solution treated specimen investigated by Wedge Opening Loading tests.
$4 \cdot 2$ 破損ダイヤフラムの水素拡散シミュレーション ダイヤフラム中の水素濃度分布の経時変化を調べるた めに, ダイヤフラムを外径 $7 \mathrm{~mm}$ ，内径 $4 \mathrm{~mm}$ の円筒とみ なし, 円筒内面から水素が侵入し, 外面から水素が放出 するものとして拡散方程式を解いた。 円柱座標系に扔け る拡散方程式と境界条件を以下に示す。

$$
\frac{\partial C}{\partial t}=D\left(\frac{\partial^{2} C}{\partial r^{2}}+\frac{1}{r} \cdot \frac{\partial C}{\partial r}\right)
$$

(境界条件)

$$
\begin{aligned}
& r=2 \mathrm{~mm} \Rightarrow C_{\text {in }}=C_{\mathrm{H}, \text { in }} / C_{\mathrm{HS}}=1 \\
& r=3.5 \mathrm{~mm} \Rightarrow C_{\mathrm{out}}=C_{\mathrm{H}, \mathrm{out}} / C_{\mathrm{HS}}=0 \\
& t=0 \Rightarrow C(r)=C_{\mathrm{H}}(r) / C_{\mathrm{HS}}=0
\end{aligned}
$$

$r$ : 中心からの距離 $C_{\mathrm{HS}}$ : 飽和水素量 $C_{\mathrm{H}}: t$ 時間経過 後の水素濃度

境界条件は，内面（水素側表面）の水素量を飽和値とし， 外面 (大気側表面) での水素量を 0 とした. SUS630 析出 硬化材の水素の拡散係数 $D$ には, $4 \cdot 1 \cdot 1$ 項で示した $80^{\circ} \mathrm{C}$ に打ける実測值 $D_{353 \mathrm{~K}}=6.4 \times 10^{-12} \mathrm{~m}^{2} / \mathrm{s}$ を用いた.

Fig. 18 に，計算で得られた水素濃度分布を示す。約 $100 \mathrm{~h}$ でダイヤフラム中の水素量は定常状態に達すること がわかる. Fig. 2 に示すように, ダイヤフラム破損の直 前には, センサーは負荷圧力 $70 \mathrm{MPa}$, 高圧容器温度 $100^{\circ} \mathrm{C}$ ，保持時間 $100 \mathrm{~h}$ 以上の条件で繰り返し使用されて おり，その都度ダイヤフラム内の水素量は定常状態に達 していたものと考えられる。

\section{$4 \cdot 3$ 破損したダイヤフラムの応力解析}

圧力センサーダイヤフラムの使用時に打ける応力状態 を調べるために，応力解析を行った，解析には，汎用有 限要素法 (Finite Element Method, FEM) 解析ソフト ANSYS を用い 3 次元軸対称モデルを用いて行った．要 素タイプは 8 節点四角形である 2 次要素を用いた。ヤン グ率は $E=200 \mathrm{GPa}$ ，ポアソン比 $v=0.3$ とした.

き裂の発生起点と考えられる位置では，Fig. 12 に示 したように, 直径 $20 \mu \mathrm{m}$ 程度の粒界破面が複数観察され た。このことから，き裂がない場合打よびき裂がある場 合について実施した。き裂がない場合の解析モデルでは, 応力集中部であるフランジ付け根の R 部の要素サイズを， $\mathrm{R}$ 部の曲率半径 $(0.2 \mathrm{~mm})$ の $1 / 15$ 程度になるように要素 分割を行った。き裂がある場合の解析は，き裂長さ $a=$

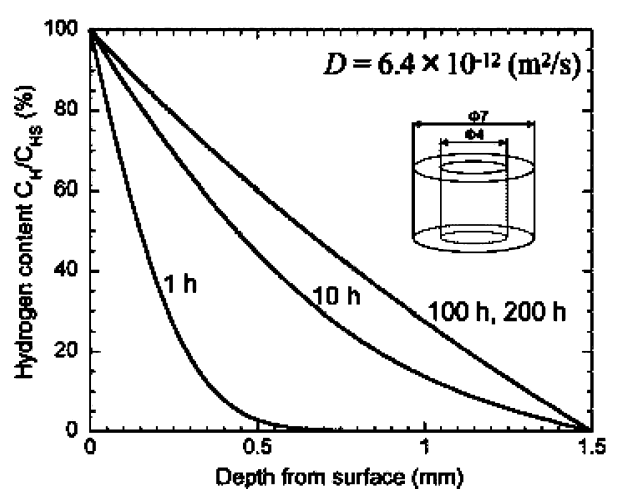

Fig. 18 Hydrogen content distribution in diaphragm 
0.02，0.1，0.5mm について行った. $a=0.02 \mathrm{~mm}$ はき裂 発生時のき裂長さを想定したものである。主応力はフラ ンジ付け根の R 部中心付近で最大となる。そこで，き裂 発生部はフランジ付け根の R 部中心と仮定した.

また, Fig. 8 (b)に示したように，き裂はフランジ R 部 近傍ではダイヤフラム軸方向に対して約 $45^{\circ}$ をす方向 に進展したのち, 内面付近になるとダイヤフラム軸方向と 垂直な方向に進展する。そこで，き裂は $0.5 \mathrm{~mm}$ までフラ ンジ部に対して $45^{\circ}$ 方向に進むと仮定した。解析には 3 次 元軸対称モデルを用いたので，き裂はダイヤフラムのフラ ンジ付け根の R 部全周に一様な深さで発生，進展してい ることになる。き裂先端近傍での要素分割は，き裂先端近 傍の応力分布の特異性が失われないように，き裂先端の 節点間距離がき裂長さ $a$ の $4 \times 10^{-5}$ 以下になるように十 分小さく分割した. Fig. 19 にき裂長さが $0.5 \mathrm{~mm}$ の場合の 解析に打ける要素分割図を示す。

Fig. 20 に解析を行ったダイヤフラムの荷重条件を示 す.ダイヤフラムは, 締付けボルトにより図の下面に押 し付けられ, 固定されている (Fig. 3 参照)。このモデル で内圧 $P$ が $0 \mathrm{MPa}$ と $70 \mathrm{MPa}$ のときの応力解析を行った. 締付けボルトの締付けトルクが $39.2 \mathrm{~N}-\mathrm{m}$ であることか ら, 締付け部の摩擦係数を 0.15 と仮定し, ダイヤフラム フランジ部に加わる押さえ付け圧力を計算した結果, 約 $900 \mathrm{MPa}$ となった。

Fig. 21 と Fig. 22 に，き裂がない場合の主応力 $\sigma_{1}$ の コンター四を示す。最大主応力 $\sigma_{1 \max }$ はフランジ付け根 の R 部で生じる。 $70 \mathrm{MPa}$ 水素ガスが作用している場合 (Fig. 21) と作用していない場合 (Fig. 22) にかかわらず, 最大主応力 $\sigma_{1 \mathrm{max}}$ は最大で約 $4000 \mathrm{MPa}$ にもなり, 硬さ から推定される材料の引張強さ $1370 \mathrm{MPa}\left(\sigma_{\mathrm{B}}=3.26 \mathrm{HV}=\right.$ $3.26 \times 420)$ を大きく超えている。したがって，センサー 組み付け時点で，フランジ付け根の $\mathrm{R}$ 部は局部的な塑性

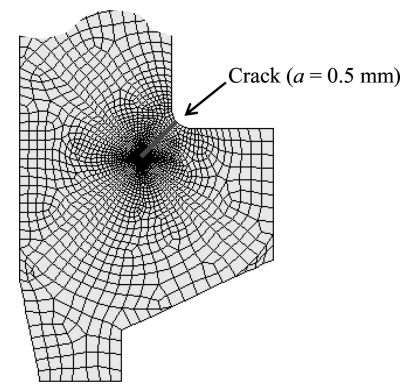

Fig. 19 FEM analysis model. $(a=0.5 \mathrm{~mm})$

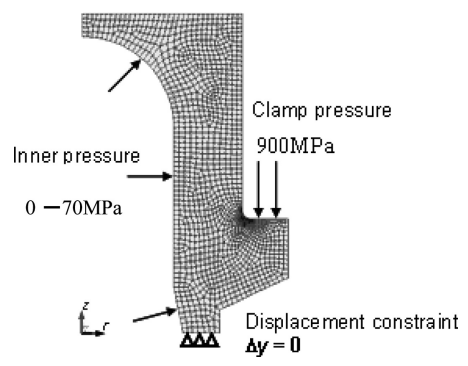

Fig. 20 Boundary conditions

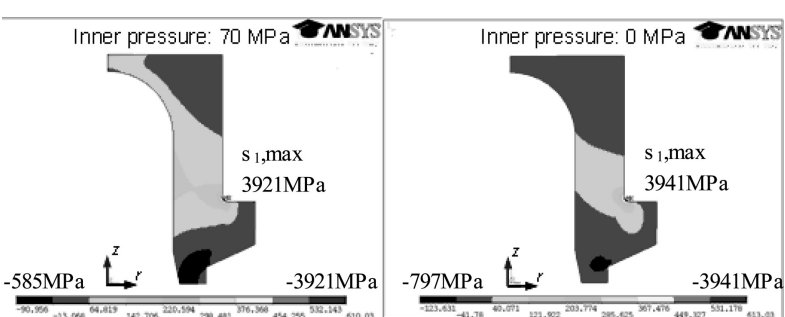

Fig. 21 Contour figure of Fig. 22 Contour figure of principle stress $\sigma_{1}$. $(P=70 \mathrm{MPa})$ principle stress $\sigma_{1}$. $(P=0 \mathrm{MPa})$

変形を起こし，さらに微小き裂を発生させていた可能性 もあると判断される。また，Fig. 21 と Fig. 22 から，内 圧が $0 \mathrm{MPa}$ から $70 \mathrm{MPa}$ に変化しても， $\sigma_{1 \max }$ はほとんど 変化しないことがわかる。したがって, 圧力振幅による き裂進展すなわち疲労き裂進展は無視でき, 静的応力に よるき裂進展が支配的と判断される。

\section{5 ダイヤフラム破損原因の推定}

Table 2 の化学成分, Fig. 6 のビッカース硬さ, Fig. 7 の組織から，ダイヤフラムはSUS630 の析出硬化材で作 られており，その材質は正常であったと推定できた。そ こで，第 3 章と第 4 章の結果を基にすると，ダイヤフラ 厶破損の原因は次のように推定できる.

(1) Fig. 22 の応力解析からわかるように, ダイヤフラム の取り付け時にはフランジ付け根の $\mathrm{R}$ 部の最大主応 力は, $\sigma_{1 \max }=3941 \mathrm{MPa}$ となる.この $\sigma_{1 \max }$ は硬さ から推定される引張強度 $\sigma_{\mathrm{B}}=1370 \mathrm{MPa}$ よりはるか に大きいので， $\mathrm{R}$ 部には塑性変形が生じ，微小き裂 が発生する. Fig. 10 と Fig. 12 で示した粒界破面が フランジ R 部に発生した微小き裂であると推定でき る。すなわち，フランジ $\mathrm{R}$ 部には大きな応力集中に より複数の粒界き裂(長さ：約 $20 \mu \mathrm{m}$ ) が形成される (Fig. 11 (a)).

(2) 高圧水素がダイヤフラムに負荷されると, Fig. 18 に示すように水素はダイヤフラム中に侵入する。 $70 \mathrm{MPa}$ 水素を負荷した場合のダイヤフラム内面での 飽和水素量 $C_{\mathrm{HS}}$ を式 (3)〜 (5) を用いて求めると，ダ イヤフラムの温度が Table 1 の圧力容器の最高温度 $125^{\circ} \mathrm{C}$ に達している場合には $C_{\mathrm{HS}}=8.2$ mass.ppm と なり , ダイヤフラムの温度が真夏の室内の気温 $35^{\circ} \mathrm{C}$ に達している場合には $C_{\mathrm{HS}}=6.0 \mathrm{mass} . \mathrm{ppm}$ となる. 破損を生じたダイヤフラムのフランジ付け根の R 部 には塑性域が存在し，その弾塑性境界で三軸引張応 力 (逆静水圧) が最大となる。三軸引張応力領域に は水素が集まるので，フランジ R 部近傍には Fig. 18 の解析結果 $(P=70 \mathrm{MPa}$ のときの弾塑性境界に相 当する位置での水素量は $125^{\circ} \mathrm{C}$ で 0.76 mass.ppm, $35^{\circ} \mathrm{C}$ で 0.54mass.ppm）よりも多くの水素が存在する.

（3）粒界き裂が，フランジ $\mathrm{R}$ 部近傍に集積した水素で助 長され，進展する。すなわち，水素助長割れが進行 する. Fig. 23 に，き裂長さ $a=0.02 \mathrm{~mm}, 0.1 \mathrm{~mm}$ ， $0.5 \mathrm{~mm}$ のときの応力拡大係数 $K$ を計算した結果を 


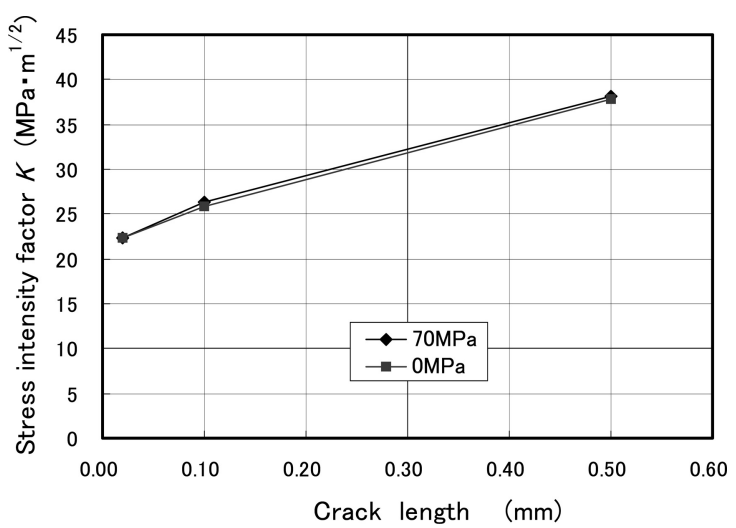

Fig. 23 Calculated $K$ value at the point close to crack tip.

示す.ダイヤフラム取り付け時に発生したと推定し た長さ $20 \mu \mathrm{m}$ の粒界き裂では $K=22.4 \mathrm{MPa} \sqrt{\mathrm{m}}$ と なる。

Fig. 17 の溶体化処理材 (HV 344) の $K_{\mathrm{th}, \mathrm{H}}$ と析出硬化 材 (HV 433) の $K_{\mathrm{th}, \mathrm{H}}$ とが等しいと仮定して, $K=22.4 \mathrm{MPa}$ $\sqrt{\mathrm{m}}$ に相当する水素量を求めると $1.8 \mathrm{mass} . \mathrm{ppm}$ となる. (2)で示したようにフランジ R 部の弾塑性境界の位置にお ける Fig. 21 の解析結果すなわち応力誘起拡散を考慮し ていない場合の水素量は 0.54 mass.ppm $\left(35^{\circ} \mathrm{C}\right)$ または 0.75 mass.ppm $\left(125^{\circ} \mathrm{C}\right)$ であるが，応力誘起拡散を考慮 すれば 1.8 mass.ppm 以上まで上昇することが考えられる. この結果，(1)で示した微小き裂が進展して破損に至った ものと考えられる。したがって，圧力センサーの少量水 素漏洩はダイヤフラムのフランジ $\mathrm{R}$ 部から生じた水素助 長割れが原因であったと推定できる.

水素漏洩を起こした圧力センサーは $150 \mathrm{MPa}$ 対応の 市販品で，水素ガス中ではメーカ保証はないものであっ た。き裂が入ったダイヤフラムの材料 SUS630 (17-7PH)

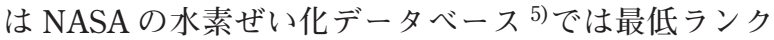
(Extremely embrittlement) に位置づけられている. 最近 では，SUH660（A286）のような水素ぜい化に対して良い 信頼性を示すセンサーも開発されている. ${ }^{6}$ A286 はNASA データベースでは最高ランク (Negligibly embrittlement) に位置づけられている。今後, 燃料電池自動車や水素ス テーションなどの水素インフラを普及させていくために は，材料選択に加え，センサーの形状や構造に新しい工 夫も取り入れ，多くの圧力センサーが使用されることを考 えると, 低コストで信頼性が高い高圧水素ガス用圧力セン サーの開発が必要である。

\section{6 結}

\section{言}

高圧水素曝露容器実験設備に使用されていた水素圧力 センサーから少量の水素ガスが漏洩した。水素ガスは圧 カセンサーに組み入れられていた SUS630 製のダイヤフ ラムのフランジ付け根の $\mathrm{R}$ 部に生じていたき裂を通って 漏洩した。フランジ $\mathrm{R}$ 部でき裂が発生・進展した原因を 調べるため，圧力センサーメーカの協力による設計情報 の入手，使用履歴の調査に加え，ダイヤフラムの破面観
察を行った。ささに，水素の関与を解析する目的で別に 採取したSUS630 を用い，水素拡散速度と飽和水素量の 測定を実施し，この結果を基にダイヤフラムへの侵入水 素濃度分布を計算した。更に，高圧水素に曝露した WOL 試験片による静的荷重下でのき裂進展試験を実施 し, 水素量と下限界応力拡大係数 $K_{\mathrm{th}, \mathrm{H}}$ の関係も求めた. これらの結果とダイヤフラムの FEM 応力解析の結果を 総合し，破損は，ダイヤフラム取り付け時にフランジ R 部に発生した粒界き裂（長さ：20 $\mu \mathrm{m} ）$ が水素に助長さ れて進展したことが原因であると推定できた。

今回の破損は，ダイヤフラムに水素ぜい化し易い SUS630 を用いていたため，ダイヤフラム固定用ねじの締 付けトルクで発生した静応力のもとで水素ぜい化割れが 進行したことが原因であると言える。しかしながら，本高 圧水素実験設備導入時に耐水素性を保証したセンサーが 無く，本センサーを採用せざえるを得なかったことが発端 となっている. 今後, 燃料電池自動車や水素ステーション などの水素インフラを普及させていくためには，材料選択 に加え，センサーの形状や構造に新しい工夫を取り入れ， 低コストで信頼性が高い高圧水素ガス用圧力センサーの 開発が必要である。このためには，本論文で示したよう に, 水素ぜい化の研究に加え, 実験設備や実証設備で起 こる破損・損傷事例解析の積み重ねが不可欠である.

本研究の一部は NEDO「水素先端材料科学基礎研究 事業」(平成 $21 \sim 22$ 年度) の一環として行われたもの である。

\section{参 考 文 献}

1) C. D. Beachem, "A new model for hydrogen-assisted cracking (Hydrogen "Embrittlement”)”, Metallurgical Transactions, pp.437-451 (1972).

2) Y. Fukai, K. tanaka and H. Uchida, “Suiso to Kinzoku”, (1998) Uchida-rokakuho, Tokyo.

3 ) C.San Marchi, B.P.Somerday and S.L. Robinson,"Permeability, solubility and diffusivity of hydrogen isotopes in stainless steel”, International Journal of Hydrogen Energy, Vol.32, pp.100-116 (2007).

4 ) T-P. Perng, M. Johnson and C. T. Altstetter, "Influence of plastic deformation on hydrogen diffusion and permeation in stainless steel”, Acta. Metallurgica, Vol.37, No.12, pp.3393-3397 (1989).

5 ) "Safety Standard for Hydrogen and Hydrogen System”, NSS 1740. 16, NASA.

6) Nagano Keiki Co. LTD., "Development of pressure measurement technology for high pressure hydrogen”, Report on FY2005-FY2007 Results, Development for Safe Utilization and Infrastructure of Hydrogen Project, New Energy and Industrial Technology Development Organization (NEDO), May (2008). 